\title{
Serum Ca 15-3: A Useful Tumor Marker in the Prognostication of Locally Advanced Breast Cancer
}

\author{
Mohd Rafey ${ }^{1}$, Kafil Akhtar ${ }^{1 *}$, Atia Z Rab ${ }^{2}$ and Shahid A Siddiqui ${ }^{3}$ \\ 'Department of Pathology, Jawaharlal Nehru Medical College, A.M.U., Aligarh, India. \\ ${ }^{2}$ Department of General Surgery, Jawaharlal Nehru Medical College, A.M.U., Aligarh, India. \\ ${ }^{3}$ Department of Radiotherapy, Jawaharlal Nehru Medical College, A.M.U., Aligarh, India.
}

\begin{abstract}
Locally advanced breast cancer (LABC) continues to be a common presentation of breast cancer worldwide. Various serum markers have been studied to know the behaviour, metastasis and prognosis of breast cancer without going through any invasive procedure. CA 15-3 measures the protein product of the MUC 1 gene and is the most commonly used serum marker in breast cancer. The main use of serum CA 15-3 is monitoring therapy response and elevated levels are associated with metastatic disease and in non-metastatic patients, it is associated with poor prognosis. The aim of the study was to know the role of serum CA 15-3 level in diagnosis, prognosis and therapy response in patients with locally advanced breast cancer and to assess its relationship with other variables like tumor size, microscopic grade, nodal burden and Ki-67 antigen expression. Serum CA 15-3 levels significantly decreased after neo-adjuvant chemotherapy and mastectomy and it remained elevated in patients with suspected or hidden metastasis. Serum CA 15-3 levels exhibited positive statistically significant correlation with tumor size.
\end{abstract}

Keywords: LABC, CA 15-3, Serum Marker.

\section{Introduction}

Locally advanced breast cancer (LABC) continues to be a common presentation of breast cancer worldwide. Patients with subset of stage IIB (T3N0) and III of the TNM classification are included in LABC. In this classification system, patients are included if they have tumor greater than $5 \mathrm{~cm}$ or that involve the skin and chest wall. Locally advanced disease also includes patients with fixed axillary lymph nodes or ipsilateral supraclavicular, infraclavicular or internal mammary nodal involvement. Inflammatory breast carcinoma (IBC) is also included in this category. ${ }^{1}$ Multidisciplinary therapy has become the treatment of choice for these patients. ${ }^{2}$

Various serum markers have been studied to know the behaviour, metastasis and prognosis of breast cancer without going through any invasive procedure. These serum markers are serum Her-2neu, serum CEA and serum CA 153. CA 15-3 in serum is better and independent prognostic tool than Her-2neu in tissue. ${ }^{3}$ CA 15-3 measures the protein product of the MUC 1 gene and is the most commonly used serum marker in breast cancer. ${ }^{4}$ The main use of serum CA $15-3$ is monitoring therapy response and elevated levels are associated with metastatic disease and in non-metastatic patients, it is associated with poor prognosis. ${ }^{5}$
The aim of the study was to know the role of serum CA 15-3 level in diagnosis, prognosis and therapy response in patients with locally advanced breast cancer and to assess its relationship with other variables like tumor size, microscopic grade, nodal burden and Ki-67 antigen expression.

\section{Material and Methods}

This study was conducted in Jawaharlal Nehru Medical College, AMU, Aligarh on 50 women diagnosed with breast cancer by true cut/core-cut biopsy. Blood samples were taken from the patients prior to chemotherapy/ surgical treatment and after 3 cycles of chemotherapy and modified radical mastectomy. Samples were preserved at $-20^{\circ} \mathrm{C}$ and CA $15-3$ was calculated by enzyme linked immunoassay kit based on ELISA method. The CA 15-3 ELISA KIT is a solid phase enzyme-linked immunosorbent assay based on the sandwich principle. The microtitre wells are coated with a monoclonal antibody directed towards a unique antigenic site on a CA 15-3 molecule. The CA 15-3 ELISA test is based on the principle of a solid phase enzyme-linked immunosorbent assay. Serum CA 15-3 level of $\leq 30 \mathrm{U} / \mathrm{ml}$ was taken as normal and a value $>30 \mathrm{U} / \mathrm{ml}$ was considered as elevated. Histopathological assessment was done by hematoxylin and eosin staining and Ki-67 antigen expression was assessed by Ki-67 
immunostaining. Statistical correlation was done by chisquare test and fisher exact test wherever applicable.

\section{Observations}

The age of the 50 patients was between 23 to 70 years with a mean age of 47.4 years and majority of the patients were in the $5^{\text {th }}$ decade of life.

Out of the 50 patients of locally advanced breast cancer, $48(96.0 \%)$ cases were of Infiltrating ductal carcinoma and $1(2.0 \%)$ case each of medullary carcinoma and NonHodgkin's lymphoma. Thirty patients $(60.0 \%)$ had tumor size beyond $5 \mathrm{cms}$ and $20(40.0 \%)$ cases had tumor size between $2-5 \mathrm{cms}$ in the present study. Out of these 50 patients, $35(70.0 \%)$ patients presented with stage III and $15(30.0 \%)$ cases presented with stage IIb disease.

Lymph node metastasis was detected in 20 (40.0\%) patients in our study. Twenty-five $(50.0 \%)$ cases presented with microscopic grade II, $15(30.0 \%)$ cases with microscopic grade I and $10(20.0 \%)$ cases presented with microscopic grade III disease.

In our present study $41(82.0 \%)$ patients had raised serum CA 15-3 level (>30U/ml) and $9(18.0 \%)$ patients had normal serum CA $15-3$ level $(\leq 30 \mathrm{U} / \mathrm{ml})$ with pre-treatment serum CA 15-3 level before neo-adjuvant chemotherapy. After neo-adjuvant chemotherapy and modified radical mastectomy, out of 45 patients, $36(80.0 \%)$ patients had normal serum CA 15-3. The statistical correlation between pre-chemotherapy and post-chemotherapy serum CA 15-3 level was statistically significant in our study ( $p$ $<0.00001$ ) (Table 1).

Out of 20 cases with tumor size 2-5 cm, serum CA 15-3 was raised $(>30 \mathrm{U} / \mathrm{ml})$ in $13(65.0 \%)$ cases and normal $(\leq 30 \mathrm{U} / \mathrm{ml})$ in $7(35.0 \%)$ cases; while $28(93.3 \%)$ cases out of 30 with tumor size $>5 \mathrm{~cm}$ had raised $(>30 \mathrm{U} / \mathrm{ml})$ serum CA $15-3$ and only $2(6.7 \%)$ cases had normal $(\leq 30 \mathrm{U} / \mathrm{ml})$ of serum CA 15-3 level. The statistical correlation between pre-chemotherapy serum CA 15-3 level and tumor size was statistically significant in our study $(\mathrm{p}=0.021)$.

Twenty (40.0\%) patients of locally advanced breast cancer showed ipsilateral lymph node metastasis in our study. Out of these 20 patients, $18(90.0 \%)$ had raised $(>30 \mathrm{U} / \mathrm{ml})$ serum CA $15-3$ with a mean value of $89.0 \mathrm{U} / \mathrm{ml}$. Out of 30 cases without ipsilateral lymph node metastasis, 23 (76.7\%) cases had raised serum CA 15-3 level with a mean value of $35.4 \mathrm{U} / \mathrm{ml}$. Although mean pre-chemotherapy serum CA 15-3 level was higher with lymph node metastasis but statistical correlation between lymph node metastasis and pre-chemotherapy serum CA 15-3 was insignificant in our study which may due to small sample size $(\mathrm{p}=0.284)$. While there was no significant correlation between prechemotherapy serum CA 15-3 level and lymph node status but mean serum CA 15-3 was higher in cases with nodal metastasis $(p=0.284)$.

In our study, out of 15 cases of locally advanced breast cancer with microscopic grade I disease, 12 (80.0\%) cases had raised serum CA 15-3 level. Out of 25 cases with grade II disease, 21(84.0\%) cases had raised (>30 U/ml) serum CA 15-3 level and out of 10 cases of locally advanced breast cancer with grade III breast cancer, 08 (80.0\%) cases had raised serum CA 15-3 level. Correlation between pretreatment serum CA 15-3 level and microscopic grade of tumor in our study was found to be statistically insignificant $(\mathrm{p}=0.934)$.

In the present study, 16 out of 20 cases $(80.0 \%)$ with low mitotic activity index had raised $(>30 \mathrm{U} / \mathrm{ml})$ serum CA $15-3$ level. Out of 22 cases with intermediate mitotic activity index, $19(86.4 \%)$ cases had raised $(>30 \mathrm{U} / \mathrm{ml})$ and out of 08 cases with high mitotic activity index, 06 (75.0\%) cases had raised serum CA 15-3 level. Our study did not show any significant correlation between mitotic activity index and serum CA 15-3 level $(\mathrm{p}=0.739)$.

Twelve cases each out of $15(80.0 \%)$ cases with low and high Ki-67 expression, had raised ( $>30 \mathrm{U} / \mathrm{ml}$ ) prechemotherapy serum CA 15-3 level and out of 20 cases with intermediate expression of $\mathrm{Ki}-67,17(85.0 \%)$ had raised pre-chemotherapy serum CA 15-3 level. Hence, our study showed insignificant correlation between serum CA 15-3 and Ki-67 expression $(p=0.903)$. Similarly, there was not significant correlation between pre-chemotherapy serum CA 15-3 level and microscopic grade $(p=0.934)($ Table 2$)$.

\section{Discussion}

In our study pre-chemotherapy CA 15-3 was elevated $(>30 \mathrm{U} / \mathrm{ml})$ in $41(82.0 \%)$ cases and normal $(\leq 30 \mathrm{U} / \mathrm{ml})$ in 09 (18.0\%), with a mean serum CA $15-3$ level of $58.3 \mathrm{U} /$ ml. Gautam et al found elevated serum CA 15-3 value in around $57.0 \%$ cases of breast cancer with mean value of 45.9 U/ml. ${ }^{6}$ Hiba et al studied serum CA 15-3 level in breast cancer and found sensitivity and specificity of $93.3 \%$ and $96.0 \%$ respectively with a mean serum CA $15-3$ value of $87.0 \pm 23.5 \mathrm{U} / \mathrm{ml}^{7}$

After 3 cycles of chemotherapy and modified radical mastectomy, serum CA 15-3 level was re-evaluated. Out of 45 patients, $36(80.0 \%)$ patients had normal CA 15-3 and only 09 (20.0\%) patients had high serum CA 15-3 level with a mean value of $22.91 \mathrm{U} / \mathrm{ml}$ in our study. This 
Table 1: CA 15-3 value before and after neo-adjuvant chemo therapy in carcinoma breast.

\begin{tabular}{|l|c|c|c|c|}
\multirow{2}{*}{ Type of carcinoma breast } & \multicolumn{2}{|c|}{ Value $\leq 30 \mathrm{U} / \mathrm{ml}$} & \multicolumn{2}{c|}{ Value > $30 \mathrm{U} / \mathrm{ml}$} \\
& $\begin{array}{c}\text { Pre- chemotherapy } \\
\text { No. of cases (\%) }\end{array}$ & $\begin{array}{c}\text { Post -chemotherapy } \\
\text { No. of cases (\%) }\end{array}$ & $\begin{array}{c}\text { Pre- chemotherapy } \\
\text { No. of cases (\%) }\end{array}$ & Post-chemotherapy \\
No. of cases (\%)
\end{tabular}

$p$ value $<0.00001$ (chi-square test)

Table 2: Level of significance of pre-chemotherapy CA 15-3 with different tumor characteristics.

\begin{tabular}{|c|c|c|c|}
\hline Variables & No. of cases & Cases with CA 15-3 (>30 U/ml) & p value \\
\hline Tumor size & \multirow{2}{*}{20} & \multirow{2}{*}{13} & \multirow{3}{*}{0.021} \\
\hline $2-5 \mathrm{~cm}$ & & & \\
\hline$>5 \mathrm{~cm}$ & 30 & 28 & \\
\hline Lymph node status & \multirow{2}{*}{20} & \multirow{2}{*}{18} & \multirow{3}{*}{0.84} \\
\hline Metastasis to lymph node present & & & \\
\hline Metastasis to lymph node absent & 30 & 23 & \\
\hline Microscopic grade & \multirow{2}{*}{15} & \multirow{2}{*}{12} & \multirow{4}{*}{0934} \\
\hline Grade I & & & \\
\hline Grade II & 25 & 21 & \\
\hline Grade III & 10 & 08 & \\
\hline Ki-67 expression & \multirow{2}{*}{15} & \multirow{2}{*}{12} & \multirow{4}{*}{0.903} \\
\hline Low & & & \\
\hline Intermediate & 20 & 17 & \\
\hline High & 15 & 12 & \\
\hline Mitotic activity index & \multirow{2}{*}{20} & \multirow{2}{*}{16} & \multirow{4}{*}{0.739} \\
\hline Mild & & & \\
\hline Moderate & 22 & 19 & \\
\hline High & 08 & 06 & \\
\hline
\end{tabular}

statistically significant decrease in serum CA 15-3 level after neo-adjuvant chemotherapy and mastectomy ( $p$ value $<0.00001)$ is in concordance with the study by Gautam et al, who reported decrease in serum CA 15-3 after neo-adjuvant chemotherapy and mastectomy. ${ }^{6}$ Similarly, Hiba et al showed decrease in serum CA 15-3 value after chemotherapy and surgery with post-operative/ post-chemotherapy mean serum CA 15-3 value of 62.39 $\mathrm{U} / \mathrm{ml}$ as compared to the pre-treatment value of $87.0 \mathrm{U} / \mathrm{ml}$ in their study. ${ }^{7}$
In the present study, out of 50 patients of locally advanced breast cancer, $30(60.0 \%)$ cases had tumor size beyond $5 \mathrm{cms}$ and only $20(40.0 \%)$ cases had tumor size between $2-5 \mathrm{cms}$. Out of 30 cases with tumor size beyond $5 \mathrm{cms}$, $28(93.3 \%)$ cases had raised (>30 U/ml) serum CA 15-3 and only $2(6.7 \%)$ cases had normal $(\leq 30 \mathrm{U} / \mathrm{ml})$ serum CA 15-3 level with a mean serum CA 15-3 level of $72.7 \mathrm{U} / \mathrm{ml}$. Out of 20 cases with tumor size $2-5 \mathrm{cms}, 13(65.0 \%)$ cases had raised serum CA $15-3$ and 7 (35.0\%) cases had normal 
serum CA 15-3 level with a mean value of $33.2 \mathrm{U} / \mathrm{ml}$. Pretreatment serum CA 15-3 levels were significantly higher in patients with large tumors in our study $(p=0.021)$. Our findings are in concordance with the studies of Yingbo et al, Sandri et al and Adela et al. ${ }^{8-10}$ Yingbo et al reported elevated levels of serum CA 15-3 in large sized tumors. ${ }^{8}$ They noticed elevated serum CA 15-3 levels in 29.0\% cases with tumor size beyond $5 \mathrm{cms}$ and $12.8 \%$ cases with tumor size between 2-5 cms had elevated serum CA 15-3 level in their study. Similarly, Duffy et al reported mean serum CA 15-3 value of $24.2 \mathrm{U} / \mathrm{ml}$ with tumor size between $2-5 \mathrm{cms}$ and $37.2 \mathrm{U} / \mathrm{ml}$ with tumor size beyond $5 \mathrm{cms}^{5}$ Also, Sandri et al reported mean serum CA 15-3 value of $18.5 \mathrm{U} / \mathrm{ml}$ with tumor size between $2-5 \mathrm{cms}$ and $27.6 \mathrm{U} / \mathrm{ml}$ with tumor size beyond $5 \mathrm{cms} .{ }^{9}$ Adela et al also reported statistically significant positive correlation between tumor size and serum CA 15-3 level. ${ }^{10}$

Statistical correlation between lymph node metastasis and pre-chemotherapy serum CA 15-3 was insignificant in our study which may due to small sample size $(\mathrm{p}=0.284)$. Hiba et al also reported no significant statistical correlation between nodal metastasis and serum CA 15-3 level. ${ }^{7}$ Our findings were discordant with the studies of Yingbo et al, San-Gang $\mathrm{Wu}$ et al and Lee et al, who have reported significant correlation between nodal burden and serum CA 15-3 level. ${ }^{8,11,12}$ San-Gang Wu et al reported axillary lymph node metastasis in $8.0 \%$ patients with normal serum CA 15-3 level and 17.0\% patients with raised serum CA 15-3. ${ }^{11}$ Similarly, Yingbo et al reported elevated levels of serum CA $15-3$ in $11.9 \%$ cases with N0 nodal status, in $12.0 \%$ cases with $\mathrm{N} 1$ nodal status, in $26.7 \%$ cases with N2 nodal status and in $19.2 \%$ cases with N3 nodal status. ${ }^{8}$ Duffy et al, reported mean serum CA 15-3 level of $26.3 \mathrm{U} /$ $\mathrm{ml}$ in cases with axillary lymph node metastasis and 21.2 $\mathrm{U} / \mathrm{ml}$ in cases without lymph node metastasis. ${ }^{5}$ Similarly, Lee et al reported mean serum CA 15-3 level increased from $11.6 \mathrm{U} / \mathrm{ml}$ in $\mathrm{N} 0$ to $14.6 \mathrm{U} / \mathrm{ml}$ in $\mathrm{N} 3$ nodal status in cases of metastatic breast carcinomas. ${ }^{12}$

Our study showed insignificant correlation between serum CA 15-3 and Ki-67 expression ( $p=0.903)$. Our study is in concordance with the study by Yingbo et al, who reported insignificant correlation between $\mathrm{Ki}-67$ antigen expression and serum CA 15-3 level. ${ }^{8}$ However, Sandri et al reported statistically significant correlation between Ki-67 antigen expression and serum CA 15-3 level. ${ }^{9}$

Correlation between pre-treatment serum CA 15-3 level and microscopic grade of tumor in our study was found to be statistically insignificant $(p=0.934)$ and in concordance with the study by Di-Gioia et al and Lee et al who did not report any significant correlation between microscopic grade of breast cancer and serum CA 15-3 level. ${ }^{3,12}$ Sandri et al, however, showed statistically significant positive correlation between microscopic grade of breast cancer and serum CA 15-3 level and reported mean serum CA 15-3 level of $15.4 \mathrm{U} / \mathrm{ml}$ in grade $\mathrm{I}, 16.6 \mathrm{U} / \mathrm{ml}$ in grade II and $18.7 \mathrm{U} / \mathrm{ml}$ in grade III breast cancers. ${ }^{9}$

\section{Conclusions}

Serum CA 15-3 is the most commonly used tumor marker in locally advanced breast cancer and is very helpful in the follow-up and monitoring the treatment of the patients with breast cancer. Serum CA 15-3 levels significantly decreased after neo-adjuvant chemotherapy and mastectomy and it remained elevated in patients with suspected or hidden metastasis and is usually associated with poor prognosis. Serum CA 15-3 levels exhibited positive statistically significant correlation with tumor size but did not show any statistically significant correlation with lymph node metastasis, Ki-67 expression, mitotic figure index and microscopic grade of the tumor.

\section{References}

1. Giordiano SH. Update on locally advanced breast cancer. The Oncologist 2003; 8(6): 521-530.

2. Valero V, Buzdar AU, Hortobagyi GN. Locally advanced breast cancer. Oncologist 1996; 1(1): 8-17.

3. Di Gioia, Dresse M, Mayr D, Nagel D, Heinemann V, Stieber P. Serum Her-2 in combination with CA 15-3 as a parameter for prognosis in patients with early breast cancer. Clinica Chimica Acta 2014; 440:16-22.

4. Dhafir Al-azawi, Gabrielle K, Eddy M, Michael J, Niall OH. CA 15-3 is predictive of response and disease recurrence following treatment in locally advanced breast cancer. BMC Cancer 2006; 6:220-221.

5. Duffy MJ, Duggan C, Keane R, Hill DK, McDermott E, Crown $\mathrm{J}$ et al. High preoperative CA 15.3 concentrations predict adverse outcome in node negative breast cancer: Study of 600 patients with histologically confirmed breast cancer. Clin Chem 2004; 50(3): 559-563.

6. Gautam A, Verma S, Pantola C, Verma S. Utility of CA 15.3 as diagnostic and prognostic marker in breast cancer. IOSRJDMS 2015; 14(2): 17-20.

7. Hiba QA, Mahdi NK, Al-Jowher MH. The value of CA 15.3 in diagnosis, prognosis and treatment response in women with breast cancer. JPMA 2013; 63:1138-1140.

8. Yingbo S, Xianfu S, Yaning He, Chaojun L, Hui L. Elevated levels of serum tumor markers CEA AND CA 15-3 are prognostic parameters for different molecular subtypes of breast cancer. Plos One 2015; 10(7): 1-11.

9. Sandri MT, Salvatici M, Botteri E, Passerini R, Zorzino L, Rotmensz N et al. Prognostic role of CA 15.3 in 7942 
patients with operable breast cancer. Breast Cancer Res Treat 2012; 132: 317-326.

10. Adela S, Daniel H, Christoph G, Erich FS, Christoph S, Ingolf JB. The potential role of preoperative cancer antigen CA 15.3 in prognosis of breast cancer. Int J Gynaecol Obstet 2015; 27(3): 115-119.

11. San-Gang W, Zhen-Yu H, Hong-Yue R, Li-Chao Y, Jia-Yuan
S, Feng-Yan L et al. Use of CEA and CA 15.3 to predict axillary lymph node metastasis in patient with breast cancer. J Cancer 2016; 7(1): 37-41.

12. Lee JS, Park S, Cho JH, Kim SI, Park JM, Park BW. Elevated levels of preoperative CA 15.3 and CEA serum levels have independently poor prognostic significance in breast cancer. Ann Oncol 2012; 2: 1-7.

\section{*Corresponding author:}

Dr. Kafil Akhtar, Professor, Department of Pathology, Jawaharlal Nehru Medical College, Aligarh Muslim University, Aligarh. (U.P)-India.

Email: drkafilakhtar@gmail.com 